\title{
A Isenção Previdenciária do Servidor Público e o abono de Permanência
}

\author{
Roberto Carus
}

\section{INTRODUÇÃO}

A importância da isenção da contribuição previdenciária e do abono, oferecidos aos servidores públicos em troca de sua permanência em atividade não reside apenas no incentivo financeiro, mas na possibilidade jurídica de garantir aos servidores ativos Que já se encontravam no sistema a manutenção de alguns direitos Que foram subtraídos com a reforma na previdência do setor público, a integralidade e a paridade, Que serão concedidas, excepcionalmente, como prêmio, àQueles Que retardarem a aposentadoria até completarem, cumulativamente, os requisitos de idade e contribuição previstos na letra "a", $§ 1^{\circ}$, do art. 40 da Constituição Federal.

No primeiro capítulo, procuramos estabelecer os motivos que levaram ao afastamento de significativa parcela de servidores no período Que antecedeu a reforma, assim como as condições em que estará configurado o direito a isenção ou ao abono, além de analisarmos o alcance das normas em razão de sua previsão constitucional.

Embora, na segunda parte, a isenção da contribuição previdenciária e o abono de permanência sejam analisados separadamente, percebe-se que por serem de natureza jurídica distintas emprestaram resultados jurídicos diversos às relações Que se pretendem regular, daí a substituição de um pelo outro. Como o direito à isenção ou ao abono envolve a permanência no cargo efetivo, também foram abordas as questões que tratam da troca de cargos, em consonância com as orientaçóes do Tribunal de Contas da União.

Finalmente, não obstante as referências a outros regimes previdenciários, buscamos privilegiar uma abordagem voltada aos procedimentos adotados na esfera federal. 


\section{AS ALTERAÇÕES NA PREVIdÊNCIA do SETOR PÚBLICO O ALCANCE DA NORMA ISENTIVA}

Criada com o objetivo de estimular a permanência dos servidores públicos, detentores de cargo efetivo, Que, no exercício de suas atividades, já tivessem obtido o tempo necessário à aposentadoria ou àoueles que viessem implementar as condições para tal pelas regras de transição, a isenção da contribuição previdenciária, estabelecida na EC n. ${ }^{\circ}$ 20/98, originariamente deveria ter sido aprovada junto com a norma Que prevê a contribuição previdenciária dos servidores inativos e Que, à época, fol rejeitada pelo Congresso Nacional. Era através dessa conjugação de normas que se esperava incentivar a continuidade dos atuais servidores públicos em atividade.

O clima de insegurança jurídica, instalado pelas discussões oue antecederam as reformas, acabou por influenciar no afastamento de significativa parcela dos servidores ativos Que, até aquele momento, reuniam os requisitos necessários à aposentadoria e continuavam trabalhando. Temia-se que com as novas regras se atropelassem os direitos adquiridos até então, a exemplo do Que ocorreu com a reforma do Regime Geral, Quando foram instituídas novas regras para as aposentadorias, prejudicando aqueles que contribuíram sobre valores mais elevados e tiveram Que arcar com os prejuízos decorrentes dessas mudanças ${ }^{1}$. Nas palavras de Décio Garcia Munhoz:

"E, diante da ação desagregadora dos Ministérios da Administração e da Previdência, semeando incertezas, foi impossível conter a corrida às aposentadorias precoces, pelo temor provocado em servidores Que normalmente permaneceriam na ativa se sentissem, no decorrer dos debates. um mínimo de garantia dos direitos já coneuistados. Com isso, apenas no QüinQüênio 1994/98 o total de aposentadorias concedidas superou os 100.0 mil." 2

I "Mudanças no Regime Geral - Mudança nas regras atualmente vigentes para o regime geral deveriam constituir a prioridade absoluta na reforma en discussäo. Afinal, a exigência do tempo de contribuição quando da aposentadoria, um dos grandes avanços do neoliberalismo, joga à condiçâa de cidadãos de segunda classe mais de 40,0\% da populazaão economicamente ativa - aproximadamente 35,0 milhöes de pessoas - o contingente de desempregados (16,5 milhöes) e de empregados sem carteira (18,5 milhöes). Um exército de trabalhadores incapazes de, Quando da aposentadoria, comprovar 35 anos de contribuizazo, mesmo Que tenham 40 ou mais 50 anos de trabalho. Todos enganados pela nova previdencia, pois, ainda que pagando contribuiçöes sobre salários equivalentes a dois, três ou cinco salários-mínimos, teräo de se contentar com uma aposentadoria muito inferior - a depender do tempo em que esteve no calváno do desemprego, ou como trabalhador clandestino.

Outra aberraçâo que terá de ser revista é em relação ao critério de cálculo do valor do benefício, pois com a regra atual - considerar a média aritmética simples dos salários de contribuízão do passado (com base nos maiores salários de 80,0\% de todo o periodo contributivo) - se reduz ardilosamente $o$ valor da aposentadoria;"

MUNHOZ, Décio Garcia. Previdência Social. A Reforma da Reforma. In a "Reforma da Previdência em Questão". Editora UnB: 2003. p. 247.

2 MUNHOZ. Décio Garcia. Previdência Social, A Reforma da Reforma. In a "Reforma da Previdência em Questão". Editora UnB: 2003, p. 236. 
Isso se justifica, em parte, pela redação original da PEC, com a previsão de considerar, para o cálculo dos proventos de aposentadoria e pensão, as contribuições recolhidas tanto nos Regimes Próprios ${ }^{3}$ como no RGPS e não mais a última remuneração. Por essa fórmula inviabilizava-se a percepção da integralidade dos proventos de aposentadoria. Somente após, na Comissão Especial da Câmara, houve a atteração Que permitiu aos servidores Que já se encontravam no sistema o direito à aposentadoria com base na última remuneração ${ }^{4}$.

O fato é Que a isenção oferecida ao servidor, em troca de sua permanência no serviço, fol insuficiente para conter o grande número de aposentadorias Que antecederam às reformas na previdência do setor público, resultado da postura equivocada que orientou os debates em torno dessa Questão - a previdência do setor público, denominação imprópria para a esfera federal, pois jamais existiu um regime previdenciário para o servidor público da União, apenas uma conta no Tesouro Nacional e não um fundo Que servisse para vincular os valores arrecadados dos servidores.

Décio Garcia Munhoz, assevera Que entender as razōes de não haver se buscado criar um regime previdenciário para os servidores da União é fácil, pois até o final dos anos 80 as despesas com inativos - aposentadorias e pensões - eram pequenas, pouco mais de 20\% do total das despesas com pessoal e, aí, na hipótese de se criar um novo sistema isso provocaria um aumento de gastos correntes (contribuiçôes para o INSS e para o Fundo de Pensão) equivalente a 70\% das despesas com inativos. Logo, a inexistência de um sistema de previdência do servidor foi à alternativa de menor custo escolhida e mantida persistentemente pelo Governo até que, a corrida às aposentadorias, provocada pelas campanhas publicitárias contra os servidores, Quando nos anos 90 se tentava reforçar as restrições inicialmente dirigidas ao regime geral (INSS) ${ }^{5}$, acabou comprometendo essa equaçãa. Embora se reconheça a conveniência dessa escolha, esse não foi o único fator que conduziu a inviabilidade da previdência do setor público. Senão, vejamos:

"A imposição de respeito ao equilibrio financeiro e atuarial e, mesmo a exigência de contributividade para a organização do sistema previdenciário repousam, segundo alegações oficialmente feitas pelas autoridades constituídas, na circunstância de haver uma massa atual de beneficiários Que monta, apenas na União, a Quarenta e dois por cento do total de despesas

3 Quanto a organização e funcionamento dos regimes próprios de previdência social dos servidores públicos da União, dos Estados, e do Distrito Federal, vigora a Lei n. ${ }^{\circ} 9.717$, de 27 de novembro de 1998.

Considera-se regime próprio de previdência social, o sistema de previdência estabelecido no âmbito de cada ente federativo, Que assegure, por lei, a servidor titular de cargo efetivo, pelo menos os benefícios de aposentadoria e pensão por morte previstos no art. 40 da Constituiçẵo Federal -inc. I, art. $2^{\circ}$, da Orientą̧ão Nornativa I. $^{\circ}$ O3. de 12.08.2004, da Secretaria de Previdência Social - DOU de 17.08.2004.

4 JORGE, Éder. Estudo sobre a Rcforma da Previdência. Emenda Constitucional n. ${ }^{\circ}$ 4l/2003. Jus Navigandi. Disponivel em: <http://wwwl, jus.com.br/doutrina/texto.asp?id=5508>.

5 MUNHOZ, Décio Garcia. Previdéncia Social. A Reforma da Reforma. In a "Reforma da Previdência em Questăo". Editora UnB: 2003, p. 237/238. 
realizadas com pessoal, sendo Que, em 1990, esse percentual reduziase a vinte por cento. Quaisquer Que tenham sido as causas que conduziram ao aumento flagrante do número de beneficiários (desde a implantação do regime jurídico único dos servidores sem a correspondente regulamentação da norma do art. $202, \S 2^{\circ}$, originariamente havido no sistema constitucional $\mathrm{e}$, agora, modificado pela Emenda Constitucional n. ${ }^{\circ}$ 20/98, até a política de pessoal adotada desde o primeiro governo eleito após a promulgação da Constituição de 1988), o certo é Que a passagem à inatividade de número significativo de servidores públicos sem a prévia garantia do custeio dos gastos e da existência e destinação de recursos voltados ao seu atendimento teria determinado o alegado desequilibrio financeiro e atuarial.

(...)

Parece certo, todavia, Que não apenas a inexistência de plano atuarial, mas também o descumprimento das próprias normas constitucionais vigentes pelas autoridades, Quer no Que concerne ao pagamento das contas havidas com as entidades previdenciárias estatais, Quer no Que se refere à regulamentação das normas Que estabeleciam a obrigação de compensação entre os sistemas, contribuíram, de maneira significativa e inquestionável, para a derrocada financeira e atuarial da organização estabelecida. Não há equilíbrio financeiro onde não exista equilíbrio administrativo; e não há equilíbrio administrativo onde não exista respeito ao sistema jurídico. Mudem Quantas vezes mudarem as normas: se elas não são dadas ao cumprimento estrito nada há a fazer para Que com a sua eficácia se produzam os resultados buscados pelos sistemas jurídicos." (Cármen Lúcia Antunes Rocha, in Princípios Constitucionais dos Servidores Públicos.São Paulo: Saraiva, 1999. p. 429).

Em apertada síntese, podemos dizer Que, como as conseqüências das orientações Que antecederam as reformas não tardaram a aparecer, buscou-se, através da isenção da contribuição previdenciária, estimular a permanência dos servidores públicos que já se encontravam em condições de aposentadoria e ainda permaneciam em atividade $\left(\S 1^{\circ}\right.$, art. $3^{\circ}, \mathrm{EC}$ n. ${ }^{\circ}$ 20/98), bem como àqueles que viessem a implementar as condiçóes para aposentadoria pelas regras de transição $\left(\S 5^{\circ}\right.$, art. $8^{\circ}, \mathrm{EC}$ n. $\left.{ }^{\circ} 20 / 98\right)$.

Mais tarde, procurou-se estender essa vantagem a todos os servidores Que integralizassem as condições para aposentadoria após a publicação da Emenda Constitucionał n. ${ }^{\circ} 20 / 98$ - art. $4^{\circ}$ da Lei n. ${ }^{\circ} 9.783$, de 28 de janeiro de 1999 , hoje a Lei n. ${ }^{\circ} 10.887$, de 18 de junho de 2004 (art. $7^{\circ}$ ). A legislação premiava, assim, os servidores que completassem as exigências para a aposentadoria integral pelas regras antigas, transitórias ou novas e Que optassem por permanecer em atividade. 
Embora o objetivo deste trabalho seja analisar a aplicação das normas relativas à isenção e ao abono, essas colocações são relevantes para Que possamos entender os motivos Que ensejaram a criação dessas normas, bem como as razôes pelas Quais os resultados desejados não foram alcançados, haja vista Que o período em Que o servidor permanecesse na ativa no gozo da isenção, por razōes óbvias, não poderia ser computado como tempo de contribuição, daí a substituição da isenção pelo abono.

Não se propõe aqui discutir todas as mudanças inseridas no novo modelo previdenciário, mas apenas as relativas à concessão da aposentadoria voluntária do servidor público, já que é nesse contexto Que estará configurado o direito a isençâo da contribuição previdenciária ou ao abono de permanência. Nesse sentido, temos como bem definido que após as reformas, numa mesma repartição pública haverá funcionários com até três expectativas diferentes de aposentadorias. Só daqui a cerca de 30 anos todos terão o mesmo tipo de aposentadoria. ${ }^{6}$

Àqueles que já se encontravam no serviço público e possuíam tempo suficiente para a aposentadoria (30/35 anos de serviço - mulher/homem). Para esses nada mudou, pois possuem o direito adQuirido a aposentadoria pelas regras antigas, com direito a integralidade e a paridade, ou seja, o valor do benefício é o último salário da ativa, e a correção será feita sempre na mesma data e pelo mesmo índice do reajuste dos servidores da ativa (art. $7^{\circ} \mathrm{da} \mathrm{EC}$ n. ${ }^{\circ} 4(/ 03)$.

Os que já se encontravam no serviço público e não possuíam tempo suficiente para aposentadoria, terão Que completar 30/35 anos de serviço (mulher/homem), 55/60 anos de idade (mulher/homem) e 20 anos de serviço público, sendo 10 anos na carreira e 5 anos de exercício no cargo onde se der a aposentadoria para ter direito à aposentadoria integral ${ }^{7}$ regras de transição (art. $6^{\circ}$ da $\mathrm{EC} \mathrm{n} .^{\circ} 4 \mathrm{I} / 03$ ). Assim, a integralidade será concedida, excepcionalmente, apenas como prệmio, para os que já se encontravam no sistema desde

6 OLIVEIRA, Aristeu. Reforma Previdenciária Comentada. São Paulo: Atlas, 2a Ed., 2004 p. 107/108.

7 EC n. $041 / 2003$. "Embora 0 art. $6^{\circ}$ caput ressalve a possibilidade de requerer a aposentadoria pelas normas do art. 40 da Constiluiçäo, ou nos moldes do art. $2^{\circ}$ da $E C$, que repete em parte o art. $8^{\circ}$ da $E C$ n. 201 98, referindo-se à transiçäo: 53 anos de idade, se homem, e 48, se mulher, com 35 e 30 anos de contribuição, respectivamente, e redução de 3,5\% ou $5 \%$ por cada ano antecipado em relação à idade mínima (60 anos, homem, e $55 \mathrm{mu} / \mathrm{her}$ ), resta dúvida se a paridade valerá para aqueles que optarem pelas regras de transição. Isto porque o art. 60. Parágrafo único da EC n. $41 / 2003$, utiliza a seguinte expressäo: 'Os proventos das aposentadorias concedidas conforme este artigo serão revistos na mesna proporção e na mesma data ...' (...) Assim, ao Que se vislumbra, numa primeira leilura, os servidores que se aposentarem nos termos do art. $2^{\circ}$ da EC, utilizando-se da regra de transição, não terão direito à paridade com os vencimentos dos da ativa." (grifo nosso). IORGE, Éder. Estudo sobre a Reforma da Previdencia. Emenda Constitucional n. ${ }^{\circ} 41 / 2003$. Jus Navigandi.

Disponivel em: <http:/wwwl.jus.com.br/doutrina/texto.asp?id $=5508>$. 
Que venham a implementar as condições acima. Nos demais casos de aposentadoria, vale a regra da média dos salários-de-contribuição ${ }^{8}$, ou seja, o servidor terá os proventos calculados na forma prevista no $\S 3^{\circ}$ do art. 40 da Constituição Federal (com redação dada pela EC n ${ }^{\circ}$ 4l/03, regulamentada pela Lei n. ${ }^{\circ} 10.887 / 04-$ art. $1^{\circ}$ ). Sobre a paridade (critérios de reajustes de proventos). Sonia Maria Gonçalves de Carvalho observa Que:

"Com o fim da paridade entre ativos e inativos, os benefícios dos novos servidores já não acompanharão o reajuste dos salários dos servidores ativos. Seus proventos serão corrigidos pela inflação.

Para os atuais servidores, foi estabelecida uma distinção entre os Que já podem se aposentar e os que preencherão os requisitos após a Emenda. Para aqueles, a teor do disposto no parágrafo único do art. $7^{\circ}$, fica mantida a paridade, sendo seus proventos revistos na mesma proporção e na mesma data em Que se modificar a remuneração dos servidores em atividade. Para estes, haverá uma paridade parcial, cujos critérios serão definidos em lei complementar a ser editada.

Da mesma forma, os que se enquadrarem nas regras de proventos pela média de contribuiçôes também terão correção pelos índices da inflaçâa, com definição em lei complementar."

E, finalmente, um terceiro tipo de servidor são os Que chegaram ao serviço público depois de promulgada a atual reforma previdenciária. Para estes a aposentadoria máxima será igual ao teto do INSS (R\$2.508,72 - valor de AGO 2004), e terão a chance de contribuir para um fundo de previdência complementar o Que thes garantirá uma renda melhor - regras definitivas. O art, 40 da Constituição Federal, com a nova redação Que the foi dada pelo $\S 1^{\circ}$ da EC n. ${ }^{\circ} 41 / 04$, dispóe, expressamente $\left(\S 3^{\circ}\right)$, Que para o cálculo dos proventos de aposentadoria serão consideradas as remunerações utilizadas como base para as contribuiçôes do servidor aos regimes próprios e ao regime geral. Deixa claro, portanto, Que foi retirado dos futuros servidores o direito à aposentadoria com proventos integrais, ficando o limite de suas aposentadorias vinculado ao teto da iniciativa privada. Estes não terão direito a integralidade nem a paridade.

Como cada servidor implementará as condições necessárias à aposentadoria de diferentes modos, esta visão panorâmica do novo modelo previdenciário é importante para Que se possa estabelecer Quando cada um fará jus à isenção ou ao abono, excetuando-se os celetistas, pois a expressão "servidores públicos"contida nas Emendas reformadoras abrange tão-somente os detentores de cargo efetivo.

8 GOMES, Denúbio. Emenda Constitucional n. ${ }^{\circ} 41$ e os Impactos nos Regimes Próprios de Previdência setembro de 2004. Disponível em: www.previdenciasocial.gov.br/docs/sps/dr_denubio_gomes0l ppt. Acesso em: 25/4/2005.

9 CARVALHO, Sonia Maria Gonçalves de. O servidor público e as reformas da Previdência (Emendas Constitucionais nos $20 / 98$ e 4(1/2003). Rio de laneiro: Lúmen lúris Editora, 2005 . p.37. 


\section{Atuais servidores ativos ${ }^{10}$}

\begin{tabular}{|c|c|}
\hline Como era ${ }_{x}$ segundo a EC $n_{r}{ }^{\circ} 20 / 98$ & Como fica, segundo a EC n. 41/2003 \\
\hline \multicolumn{2}{|c|}{ CRITERIOS PARA APOSENTADORIA } \\
\hline $\begin{array}{l}\text { Os servidores ingressos antes de } 16.12 .1998 \\
\text { podem se aposentar ao completar } 53 \text { anos } \\
\text { de idade e } 35 \text { anos de contriburçäo (mais } \\
\text { pedágio de } 20 \% \text { sobre o tempo que faltava } \\
\text { naquela d ata para completar o tempo de } \\
\text { contribulça), se homem, e aos } 48 \text { anos de } \\
\text { idade e } 30 \text { anos de contribucuço (mais } \\
\text { pedagio), se mulher. Em ambos os casos, e } \\
\text { necessáno ter cinco anos no cargo em que } \\
\text { se dara a aposentadoria. }\end{array}$ & 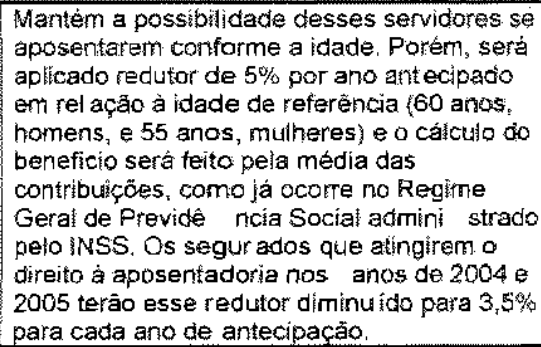 \\
\hline \multicolumn{2}{|c|}{ APOSENTADORIA PROPORCIONAL } \\
\hline $\begin{array}{l}\text { Os servidores ingressos antes de } 16.12 .1998 \\
\text { podern se aposentar ao completar } 53 \text { anos } \\
\text { de idade e } 30 \text { anos de contribuição (mais } \\
\text { pedágio de } 40 \% \text { sobre o tempo que faltava } \\
\text { naquela d ała para completar o tempo de } \\
\text { contribuiçäo), se homem, e aos } 48 \text { anos de } \\
\text { idade e } 25 \text { anos de contribuição (mais } \\
\text { pedágio), se mulher. Em ambos os casos, é } \\
\text { necessário ter cinco anos no cargo em que } \\
\text { se dara a aposentadoria. }\end{array}$ & $\begin{array}{l}\text { Prevê o direito adquitido aposentadoria } \\
\text { proporcional extingue essa possibilidade } \\
\text { para os servidores ingressos antes de } 1998 \text {. }\end{array}$ \\
\hline $\begin{array}{l}\text { ISENÇAO DA CONTRIBUIÇAO } \\
\text { PREVIDENCIARIA }\end{array}$ & ABONO DE PERMANENCIA \\
\hline 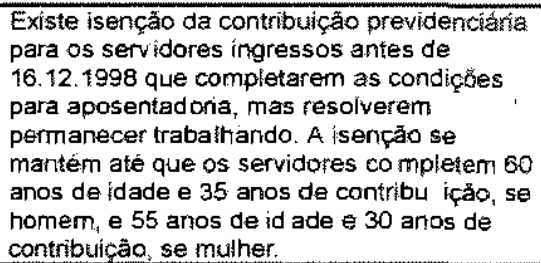 & $\begin{array}{l}\text { Cria abono equivalente à contribucháa } \\
\text { previdenciaria (11\% do salário dos servidores } \\
\text { que têm dire ito adquirido e decidam } \\
\text { permanecer em at ividade até a } \\
\text { aposentadoria compulsória aos } 70 \text { anos). }\end{array}$ \\
\hline \multicolumn{2}{|c|}{ INTEGRALIDADE E PARIDADE } \\
\hline $\begin{array}{l}\text { O valor do beneficio é o ditimo salario da } \\
\text { ativa, a correça é feita sempre na mesma } \\
\text { data e pelo mesmo indice do realustes dos } \\
\text { servidores da ativa. }\end{array}$ & $\begin{array}{l}\text { Mantidas para quem tem direito adquirido } \\
\text { pelas regras antigas. Para os demais, le näo } \\
\text { vale como regra geral. Será concedida, } \\
\text { excepcionaimente, apenas como pr êmio, } \\
\text { para os atuals servidores que trabalharem } \\
\text { até os } 60 \text { anos de idade, com } 35 \text { anos de } \\
\text { contribuiçâo (homens) ou } 55 \text { anos de idade e } \\
30 \text { anos de contribuiçso (mulheres). Em } \\
\text { ambos os casos sera preciso co ntar } 20 \text { anos } \\
\text { de serviço púbico, } 10 \text { anos de carreira e } 5 \\
\text { anos no catgo. Os critérios da patidade serảo } \\
\text { definidos em lei ordinária. }\end{array}$ \\
\hline
\end{tabular}

30 BRASIL. Ministério da Previdência e Assistência Social - MPAS. A Reforma da Previdência Social-O Oue mudou. Brasilia, DF. 2004. Disponíveł em: http://www.mpas.gov.br/reforma/l l_25_02.asp. Acesso em: 3 nov. 2004. 
Ultrapassada a Questäo Que envolve as diferenças entre os servidores, passamos a analisar o alcance da isenção proposta pela reforma. Sobre essa Questão José Maria de S. Martínez" esclarece que a análise da isençāo previdenciária requer um raciocínio jurídico diferente do solicitado para análise da aposentadoria do servidor, embora as regras sejam Quase as mesmas.

Segundo o autor, uma vez entendida a natureza jurídico-tributária da contribuição previdenciária, a sua isenção dependerá do atendimento de alguns requisitos: a) o preenchimento das condições para a aposentadoria voluntária; $b$ ) a opção de permanência em atividade; e c) para os servidores estaduais e municipais a isenção somente ocorrerá, nos moldes em Que for estabelecido pela Constituição Federal (art. 149, $\$ 10$ ), se houver previsibilidade na Constituição estadual, na lei orgânica municipal ou na legislação previdenciária Que regule a aposentadoria desses servidores.

Prossegue, afirmando Que os servidores públicos estaduais e municipais regem-se pelas legislaçōes previdenciárias de seus Estados e Municípios, e por isso não estão obrigados a submeter-se às regras de transição de um ato normativo que exaure a sua tinalidade no momento em Que modifica o corpo permanente da Constituição, como são as emendas constitucionais.

De fato, a autonomia administrativa e financeira dos Entes federados, prevista constitucionalmente, não permite Que as regras de transitoriedade contidas na $\mathrm{EC} n .^{\circ} 20 / 98$ ditem normas a serem observadas onde exista regulamentação da matéria feita por eles, em Que pese à intenção do legislador constituinte derivado de que aquelas normas sejam adotadas pelos demais Entes federados por ocasião de suas reformas constitucionais e previdenciárias, adequando-se ao novo modelo estabelecido. Para José Maria de S. Martinez,

"Não deve o legislador estadual ou municipal Quedar-se mudo e silente ao regulamento do direito à isenção previdenciária de seu servidor, interpretando norma de caráter cogente aos servidores públicos da União, como forma de preenchimento de sua lacuna legislativa." 12

Ainda, segundo o mesmo autor, somente os servidores pertencentes aos Estados e Municípios Que contribuam para o sistema previdenciário geral (INSS) é que estão sujeitos às regras de transitoriedade para a aposentadoria com proventos integrais estabelecidas no art. $8^{\circ}$ da EC n. ${ }^{\circ}$ 20/98, e, consequentemente, à isenção previdenciária. Os demais regem-se pelas regras contidas nas Constituiçóes de seus Estados e leis orgânicas de seus municípios, assim como na legislação previdenciária própria, editada após a EC n. ${ }^{\circ} 20 / 98$, ou mesmo editada anteriormente, desde Que recepcionada pelo que contém o art. 40 e $195 \mathrm{da} \mathrm{CF} / 88$, em seu corpo permanente.

"MARTÍNEZ, José Maria de S. A reforma e a isenção previdenciária do servidor. Jus Navigandi. Disponível $\mathrm{em}:<$ http://Www.jus.com.br/doutrina/texto.asp?id=4593>. Acesso em: 25/4/2005.

12 MARTÍNEZ, losé Maria de S. A reforma e a isencão previdenciária do servidor. lus Navigandi. Disponível em: <http://www.jus.com.br/doutrina/texto.asp?id=4593>. Acesso em: 25/4/2005. 
"Se, após a edição da EC n. ${ }^{\circ}$ 20/98, a lei do sistema previdenciário dos outros Entes federativos (Estados e Municípios) nāo adotou o 'pedágio' para a aposentadoria (e, consequentemente, para a isenção previdenciária) não cabe ao intérprete aplicar àoueles que já tinham obtido o direito à aposentadoria proporcional e eue vierem a completar a integralidade do tempo necessário à aposentadoria a Qualquer tempo (30 ou 35 anos de serviço ou contribuição) o disposto no $\S 5^{\circ}$, do art. $8^{\circ}$, da regra de transiç̧ão federal." 13

Em outras palavras, o disposto na Constituição Federal apenas serve de baliza para as regras a serem adotadas por Estados e Municípios e as regras de transição previstas na EC n. ${ }^{0}$ 20/98, são de caráter cogente apenas ao sistema previdenciário federal.

\section{A ISENÇÃO DA CONTRIBUIÇÃO PREVIDENCIÁRIA DO SERVIDOR PÚBLICO}

A isenção da contribuição previdenciária estabelecida no $\S 1^{\circ}$ do art. $3^{\circ} \mathrm{da}$ Emenda Constitucional n, ${ }^{\circ} 20 / 98$ contempla os servidores ativos, detentores de cargo efetivo, Que até data de sua publicação, 16.12.1998, implementaram os reQuisitos para a aposentadoria voluntária integral.

"Art. $3^{\circ}$ - É assegurada a concessão de aposentadoria e pensão, a QualQuer tempo, aos servidores públicos e aos segurados do regime geral de previdência social, bem como aos seus dependentes, eue, até a data da publicação desta Emenda, tenham cumprido os reQuisitos para a obtenção destes benefícios, com base nos critérios da legislação então vigente."

$\S 1^{\circ} \mathrm{O}$ servidor de Que trata este artigo, Que tenha completado as exigências para aposentadoria integral e Que opte por permanecer em atividade fará jus à isenção da contribuição previdenciária até completar as exigências para aposentadoria contidas no art. $40, \S 1^{\circ}, \mathrm{III}$, a, da Constituiçâo Federal."

A referida emenda também estabelece a isenção da contribuição previdenciária àQueles Que ingressaram no serviço público até 16.12 .1998 , a partir do momento em Que completarem as condições para a aposentadoria de acordo com as regras de transição $\left(\S 5^{\circ}\right.$, art. $\left.8^{\circ}\right)$.

13 MARTÍNEZ, losé Maria de S. A reforma e a isenção previdenciária do servidor. Ius Navigandi. Disponível em: <http://www.jus.com. br/doutrina/texto.asp?id =4593>. Acesso em: 25/4/2005. 
"Art. $8^{\circ}$ - Observado o disposto no art. $4^{\circ}$ dessa Emenda e ressalvado o direito a opção a aposentadoria pelas normas por ela estabelecidas, é assegurado o direito à aposentadoria voluntária com proventos calculados de acordo com o art. $40, \S 3^{\circ}$, da Constituição Federal, à quele que tenha ingressado regularmente em cargo efetivo na Administração Pública, direta, autáreuica e fundacional, até a data de publicação desta Emenda, Quando o servidor, cumulativamente:

I- tiver cinqüenta e três anos de idade, se homem, e Quarenta e oito anos de idade, se mulher:

II - tiver cinco anos de efetivo exercício no cargo em que se dará a aposentadoria;

III -- contar tempo de contribuição igual, no mínimo, à soma de:

a) trinta e cinco anos, se homem, e trinta anos, se mulher, e;

b) um periodo adicional de contribuição equivalente a vinte por cento do tempo Que, na data da publicação desta Emenda, faltaria para atingir o limite de tempo constante da alínea anterior.

\section{(..)}

$\S 5^{\circ}$ - O servidor Que trata este artigo, Que, após completar as exigências para aposentadoria estabelecidas no 'caput', permanecer em atividade, fará jus à isenção da contribuição previdenciária até completar as exigências para aposentadoria contidas no art. $4^{\circ}, \S 1^{\circ}$, III, 'a', da Constituição Federal."

Em ambas as hipóteses os servidores somente farão jus à isenção até completarem cumulativamente os requisitos de idade e contribuição fixados na alínea "a" do inc. Ill do art. $40 \mathrm{da}$ CF.

Assim, o termo final da isenção prevista no $\S^{\circ}$ do art. $3^{\circ}$ e no $\S 5^{\circ}$ do art. $8^{\circ}$, ambos da Emenda Constitucional n. ${ }^{\circ} 20 / 98$, situa-se, precisamente, no momento em Que os servidores preencherem, cumulativamente, os requisitos elencados no art. $40, \S 1^{\circ}$, "a", da Constituição Federal, Quaís sejam: a) tempo de serviço de 10 (dez) anos de efetivo exercício no serviço público; b) tempo múnimo de 5 (cinco) anos de exercício no cargo efetivo em Que se dará a aposentadoria; c) 60 anos de idade e 35 anos de contribuição, se homem; e d) 55 anos de idade e 30 anos de contribuição, se mulher. Esse entendimento é adotado no âmbito do Estado do Rio de laneiro - Lei n. 3.189 , de 22 de fevereiro de 1999 (art. 21), Que instituiu o Fundo Único de Previdência Social do Estado - Rio Previdência. ${ }^{14}$

i4 CARVALHO, Sonia Maria Gonçalves de. O servidor público e as reformas da Previdência (Emendas Constitucionais nos $20 / 98$ e 4 (/2003). Rio de Janeiro: Lúmen Júris Editora, 2005. p.6. 
Portanto, os servidores que já podiam se aposentar com proventos integrais em 16.12.1998 e Que continuavam trabalhando fazem jus, à isenção da contribuição previdenciária até completarem 60 anos de idade e 35 de contribuição, se homem, e 55 anos de idade e 30 de contribuição, se mulher. Os demais, Que ingressaram no serviço público até 16.12.1998, farão jus a mesma isenção a partir do momento em Que preencherem os requisitos para a aposentadoria com proventos integrais pelas regras de transição, desde que também continuem trabalhando, até completarem 60 anos de idade e 35 de contribuição, se homem, e 55 anos de idade e 30 de contribuiçâa, se mulher ${ }^{15}$.

Em nível federal, a Lei n. ${ }^{0} 9.783$, de 28 de janeiro de 1999 (art. $4^{\circ}$ ) - hoje, em seu lugar, a Lei n. ${ }^{\circ} 10.887 / 04$ (art. $7^{\circ}$ ) - e a Instrução Normativa SEAP n. ${ }^{\circ} 01$, de 17 de fevereiro de 1999 (art. 10), regulamentando a matéria, estabelecem, de forma diversa, Que o servidor ficará isento da contribuição até a data da concessão de sua aposentadoria voluntária ou compulsória.

Em verdade, a Lei n. ${ }^{\circ}$ 9.783/99 estendeu a vantagem a todos os servidores Que integralizassem o tempo para a aposentadoria após a $\mathrm{EC} n .^{\circ} 20 / 98$, até a data da publicação de sua aposentadoria voluntária ou compulsória, sendo o prazo máximo de permanência em atividade o estabelecido no art. $40, \S 1^{\circ}$, inc. II. da Constituição Federal, Qual seja, a idade de 70 anos, Quando se dará a aposentadoria automática, declarada por ato, com vigência a partir do dia imediato àquele Que o servidor atingir a idade-limite de permanência no serviço ativo.

"Art. $4^{\circ}$ - O servidor público civil ativo Que permanecer em atividade após completar as exigências para a aposentadoria voluntária integral nas condições previstas no art. 40, da Constituição Federal, na redação dada pela Emenda Constitucional n. ${ }^{\circ} 20$, de 15 de dezembro de 1998. Nas condições previstas no art. $8^{\circ}$ da Referida Emenda, fará jus à isenção da Contribuiçẫo Previdenciária até a data da publicação da concessão de sua aposentadoria voluntária ou compulsória."

No eue concerne a aplicação da norma, a Secretaria de Recursos Humanos do Ministério do Planejamento, órgão responsável pela interpretação e normalização da legislação federal para os demais órgãos do Poder Executivo, através do Ofício-Circular n. ${ }^{\circ} 65^{16}$, de 12 de dezembro de 2001, firmou entendimento de Que a isenção previdenciária somente será efetivada a partir da data da opção pela permanência em atividade, no exercício do cargo, "verbis":

is MEDINA, Damares. A isencäo da contribuicão previdenciária e o abono de permanéncia na Emenda Constitucional n. 4/103., Teresina, a. 8، n. 345, 17 jun. 2004. Disponivel em: <http://wwwl.jus.com.br/ doutrina/texto.asp?id $=5344>$ : Acesso em: 18 nov. 2004.

${ }^{16}$ Oficio-Circular n. ${ }^{\circ}$ 65/SRH/MP de 12.10 .2001 . Disponivel em: <http://www.servidor.govbr/legislaçao/ docs/oficio_circular/2001/of_circ_65_121101.him. Acesso em: 14 mar. 2005. 
"A isenção da obrigação de contribuir para o Plano de Seguridade Social do servidor público de que trata o art. $3^{\circ}, \S 1^{\circ}$, da Emenda Constitucional no 20. de 1998, e o art. $4^{\circ}$ da Lei $n^{\circ} 9.783$, de 28 de janeiro de 1999, será efetivada a partir da opção pela permanêncía em atividade, no exercício do cargo, apresentada pelo interessado e protocolada junto à área de recursos humanos do órgão ou entidade.

Na hipótese de averbação de tempo de serviço ou de contribuição derivados de outros vínculos funcionais ou empregatícios, inclusive de outros Poderes da União, a vigência da isenção será sempre a partir da comprovação desse período pelo interessado mediante requerimento, desde que considerado válido pelo órgão ou entidade."

Como se pode ver, não basta fazer jus à vantagem para gozar a isenção contida nos dispositivos acima transcritos. Somente após o cumprimento da condição suspensiva é que será efetivada a isenção propriamente dita, através de despacho da autoridade, mediante requerimento do interessado, não se admitindo a aplicação de efeito retroativo à data do pedido. A administração dispensa a essa isenção o mesmo tratamento dado pelo art. 179 do Código Tributário Nacional - Lei n. ${ }^{\circ} 5.172$ de 25 de outubro de 1966 - para as isençôes de caráter geral.

"Art. 179 - A isenção, Quando concedida em caráter geral, é efetivada, em cada caso, por despacho da autoridade administrativa, em reQuerimento com o Qual o interessado faça prova do preenchimento das condições e do cumprimento dos reQuisitos previstos em lei ou contrato para a sua concessão."

Assim, mesmo que o servidor já contasse com tempo sobrando para a aposentadoria voluntária, somente após delerida a isenção, por despacho da autoridade, fará jus a vantagem.

Há, contudo, Quem discorde do entendimento de Que vigência da isenção se dará a partir do ato através do Qual a administração reconhece como atendidos os requisitos legais para o gozo da isenção.

É o caso de Hugo de Brito Machado Segundo ${ }^{17}$, para Quem nem mesmo a interpretação literal do art. 179 do CTN possibilita tal entendimento. Isso porque o art. 179 do CTN não determina Que a isenção "poderá ser" efetivada, ou Que "só será efetivada", mas que "será" efetivada. E assim o faz porQue à administração somente cabe verificar o atendimento das exigências legais.

17 MACHADO SEGUNDO, Hugo de Brito. Natureza do despacho que concede isençâo tributária individual. lus Navigandi, Teresina, a. 4, n. ${ }^{\circ}$ 39, fev. 2000.

Disponivel em: <http://wwwl.jus.com.br/doutrinatexto.asp?id=| 306>. Acesso em: 24 abr. 2005. 
O autor sustenta, ainda, Que a atitude das autoridades de ignorar isenções, supostamente estribadas na literalidade do art. 179 do CTN, é inteiramente improcedente e denota o desconhecimento da própria natureza jurídica dessa forma de exclusão do crédito tributário, até porque a isenção individual, mesmo Que deferida pela autoridade em cada caso, não decorre do despacho desta, mas da lei.

Como em torno dessa Questão não são poucos os conflitos entre o Fisco e o contribuinte, Hugo de Brito cita como exemplos as abusivas e freeüentes autuaçōes do INSS, na Qual se exige a contribuição previdenciária incidente sobre o valor de cestas básicas fornecidas pelas empresas aos seus empregados, embora sejam isentas de contribuiçăo por força do art. $3^{\circ}$ da Lei n. ${ }^{0} 6.321 / 76$ e do art. $28 . \$ 9^{\circ}$, "c", da Lei n. ${ }^{0} 8.212 / 91$.

Outra demonstração ocorre com algumas empresas Que se estabelecem na Região Nordeste, Quanto à exigência de Imposto de Renda, nada obstante a isenção concedida pelos arts. 13 e 14 da Lei n. ${ }^{\circ} 4.239 / 63$ e pelo Dec. Lei n. ${ }^{\circ} 1.598 / 77$ às empresas Que se instalarem em área de atuação da SUDENE.

Nesses casos as empresas são autuadas porque não comunicaram ao Fisco o preenchimento dos requisitos para o gozo da isenção ou porque fizeram a comunicação com algum atraso. ${ }^{18}$

No caso das isenções subj̧etivas, assim chamadas poreue visam favorecer ou atingir determinada pessoa, a atitude das autoridades administrativas não é diferente, pois sustentam Que o direito ao gozo dessa vantagem nasce do despacho Que a defere.

Ocorre Que, em casos análogos Que tratam de isenção tributária, à luz da jurisprudência, essa interpretação merece reparos. Senão, vejamos:

"Imposto de Renda. Isenção reconhecida a Sociedade de fins não lucrativos, consoante os arts. 25 e 31 do Decreto n. ${ }^{\circ} 59.400$, de 10.05.66. o ato administrativo de reconhecimento tem efeito declarativo e não atributivo, abrangendo, assim, períodos anteriores a sua expedição." 19 "Imposto de Renda - Isenção relativa - Se o favor depende de reconhecimento da autoridade administrativa, o respectivo efeito, por isso Que apenas declaratório, retroage, alcançando os lançamentos efetuados desde a data da norma legal concessiva do benefício..

- Ação anulatória julgada procedente em sentença Que se confirma." ${ }^{20}$

18 MACHADO SEGUNDO, Hugo de Brito. Natureza do despacho que concede isençäo tributária individual. lus Navigandi, Teresina, a. 4, n. ${ }^{\circ} 39$, fev. 2000.

Disponível em: <http:/wwwl.jus.com.br/doutrinatexto.asp?id=1306>. Acesso em: 24 abr. 2005.

19 AC. Um. Da 2a ${ }^{\text {T }}$ do TFR - AP n. ${ }^{\circ} 36.493-M G-$ RTFR n. ${ }^{\circ} 46, p, 21$.

${ }^{20}$ Ac do TFR - Rel. Ministro Armando Rolemberg - Ap. Cível n. ${ }^{\circ}$ 57.637-MG. 
“ISENSÃO TRIBUTÁRIA ESPECIAL. INTERPRETAÇÃO DO ART. 179 do C.T.N. O ato administrativo Que a reconhece é declaratório e não constitutivo. O requerimento é pressuposto para o desfrute da isenção, mas não para o seu nascimento. Isenção especial reconhecida desde a vigência da lei que a instituiu no interesse geral, uma vez verificados os seus requisitos legais. Dissídio jurisprudencial não demonstrado. Súmula 291. RE não conhecido." ${ }^{21}$

Para Hugo de Brito Machado Segundo, o relevante no deferimento da isenção é a constatação de que os requisitos legais foram atendidos, ainda Que por outros meios, porque o despacho Que reconhece a isenção individual não é condição nine Qua non, constitutiva do direito a isenção. Nas palavras de BALEEIRO,

"(...) o direito tributário, em princípio, não adota formas sacramentais. Elas não são instituídas 'ad solenitatem', mas 'ad probationem', no interesse da apuração da verdade nas relaçôes entre o sujeito passivo e o Fisco"22

Por tudo isso, podemos concluir que ainda que o reconhecimento da autoridade fosse indispensável, a decisão administrativa apenas declara o atendimento dos requisitos legais e o direito à isenção, sendo o termo inicial da mesma o momento em Que os requisitos foram atendidos, e não a data da decisão da autoridade administrativa.

\section{O ABONO DE PERMANÊNCIA}

A Emenda Constitucional n. ${ }^{\circ} 41 / 2003$ criou o abono de permanência, equivalente ao valor da contribuição previdenciária, para todos os servidores Que, completando o tempo para a aposentadoria, optem por permanecer em atividade, tenham eles ingressado antes (art. $2^{\circ}, \S$ $5^{\circ}$, e art. $3^{\circ}, \S 1^{\circ}$ ) ou depois de sua edição (art. $1^{\circ}$, dando nova redação ao art. $\left.40, \S 19 \mathrm{da} \mathrm{CF}\right)^{23}$. até o servidor completar as exigências para aposentadoria compulsória contidas no $§ 1^{\circ}$, II.

De acordo com Damares Medina ${ }^{24}$, o abono de permanência, cuja natureza jurídica é de um benefício previdenciário, será devido em três situações distintas:

A primeira, Que diz respeito à norma geral e irretroativa do Texto Constitucional está contida no $\S 19$ do art. 40 , e estabelece o pagamento do abono de permanência aos

21 Ac. Da $2^{\text {a }}$ T do STF - Rel. Ministro Cordeiro Guerra - RE 8547|/R] - lulgado em 02.12.76, Publicado no DIU I 1 8.03.77.

22 Aliomar Baleeiro. Direito Tributário Brasileiro, $10^{2}$ Ed., Forense, Rio de laneiro, 1993, p. 598.

${ }^{23}$ CARVALHO, Sonia Maria Gonçaives de. O servidor público $e$ as reformas da Previdência lEmendas Constituclonais nos 20/98 e 41/20031. Rio de Janeiro: Lúmen Júris Editora, 2005. p.6/7.

24 MEDINA, Damares. A isenção da contribuiçäo previdenciária e o abono de permanência na Emenda Constitucional $n .041 / 03$. Jus Navigandi, Teresina, a. 8, n. 345, 17 jun. 2004. Disponivel em: <http://: wwwl.jus.com.br/doutrina/texto.asp?id $=5344>$. Acesso em: 18 nov. 2004. 
servidores públicos federais Que completarem os reQuisitos para a aposentadoria voluntária, desde Que contem com o tempo mínimo de dez anos no serviço público e cínco anos no cargo efetivo em que se dará a aposentadoria, além do requisito da idade (60 anos de idade e 35 anos de contribuição, se homem, e 55 anos de idade e 30 de contribuição, se mulher), desde que permaneçam trabalhando.

"Art. $1^{\circ} \mathrm{A}$ Constituição Federal passa a vigorar com as seguintes alterações: (...)

Art. 40. (...)

$\S 1^{\circ}$ Os servidores abrangidos pelo regime de previdência de que trata este artigo serão aposentados, calculados os seus proventos a partir dos valores fixados na forma $\operatorname{dos} \S \S 3^{\circ}$ e 17 :

(...)

II - voluntariamente, desde Que cumprido tempo mínimo de dez anos de efetivo exercício no serviço público e cinco anos no cargo efetivo em Que se dará a aposentadoria, observadas as seguintes condições:

a) sessenta anos de idade e trinta e cinco de contribuiçãa, se homem, e cinQüenta e cinco anos de idade e trinta de contribuição, se mulher;

(...)

$\S 19$. O servidor de Que trata este artigo Que tenha completado as exigências para aposentadoria voluntária estabelecidas no $\S I^{\circ}$, III, a, e Que opte por permanecer em atividade fará jus a um abono de permanência equivalente ao valor da sua contribuição previdenciária até completar as exigências para aposentadoria compulsória contidas no $\S 1^{\circ}$, Il."

A segunda e terceira menção ao abono de permanência, agora pelas regras de transição, estão contidas no $\S 5^{\circ}$ do art. $2^{\circ}$ e no $\S 1^{\circ}$ do art. $3^{\circ}$ da Emenda Constitucional n. ${ }^{\circ} 41 / 2003$.

"Art. $2^{\circ}$ Observado o disposto no art. $4^{\circ}$ da Emenda Constitucional n. ${ }^{\circ} 20$, de 15 de dezembro de 1998, é assegurado o direito de opção pela aposentadoria voluntária com proventos calculados de acordo como art. 40 , $\S \S 3^{\circ}$ e 17 da Constituição Federal, àquele Que tenha ingressado regularmente em cargo efetivo na Administração Pública direta, autárquica e fundacional, até a data de publicação daquela Emenda, Quando o servidor, cumulativamente:

1- tiver cineüenta e três anos de idade, se homem, e Quarenta e oito anos de idade, se mulher;

II - tiver cinco anos de efetivo exercício no cargo em Que se der a aposentadoria; III - contar tempo de contribuição igual, no mínimo, à soma de:

a) trinta e cinco anos, se homem, e trinta anos, se mulher; e

b) um período adicional de contribuição equivalente a vinte por cento do tempo Que, na data de publicação daquela Emenda, faltaria para atingir o limite de tempo constante da alínea a deste inciso. 
(...)

$\S 5^{\circ}$ O servidor de Que trata este artigo, Que tenha completado as exigências para aposentadoria voluntária estabelecidas no caput, e que opte por permanecer em atividade, fará jus a um abono de permanência equivalente ao valor de sua contribuição previdenciária até completar as exigências para aposentadoria compulsória contidas no art. 40 , $\S I^{\circ}$, II, da Constituição Federal.

(..)

Art. $3^{0}$ É assegurada à concessão, a qualquer tempo, de aposentadoria aos servidores públicos, bem como pensão aos seus dependentes, que, até a data de publicação desses benefícios, com base nos critérios da legislação então vigentes.

$\S 1^{\circ}$ O servidor de Que trata este artigo Que opte por permanecer em atividade tendo completado as exigências para aposentadoria voluntária $\mathrm{e}$ Que conte com, no mínimo, vinte e cinco anos de contribuição, se mulher, ou trinta anos de contribuição, se homem, fará jus a um abono de permanência equivalente ao valor da sua contribuição previdenciária até completar as exigências para aposentadoria compulsória contidas no art. 40 . $\S 10$, II, da Constituição Federal. (...)"

$O$ art. $2^{\circ} \mathrm{da} E C$ n. ${ }^{\circ} 41 / 2003$ assegura o direito a aposentadoria voluntária àQueles Que ingressaram no serviço público até a data da publicação da EC n. ${ }^{\circ}$ 20/98 (16.12.1998) e que contem com 53 anos de idade, 5 anos no cargo efetivo em Que se der a aposentadoria e 35 anos de contribuição acrescido de um período adicional de contribuição equivalente a $20 \%$ do tempo Que, em 16.12.2003, faltaria para completar os 35 anos de contribuição, se homem. Se mulher, os requisitos são: 48 anos de idade, 5 anos de efetivo exercício no cargo em Que se dará a aposentadoria e 30 anos de contribuição Que também será acrescido de um pedágio correspondente a $20 \%$ do tempo Que, em 16.12 .2003 , faltaria para completar os 30 anos de contribuiçãa.

$\mathrm{O} \S 5^{\circ}$ do art. $2^{\circ} \mathrm{da} E C \mathrm{n} .{ }^{\circ} 4 ! / 2003$ assegura, aos servidores Que ingressaram no serviço público até 16.12.1998, o pagamento de um abono de permanência correspondente à contribuiçăo previdenciária (1 1\% sobre os vencimentos), a partir do implemento dos requisitos estipulados no item anterior, enquanto o servidor permanecer na atividade ou até a aposentadoria compulsória.

$O \S 1^{\circ}$ do art. $3^{\circ}$ da $E C$ n. $.^{\circ} 41 / 2003$, por sua vez, assegura o abono de permanência a todos os servidores Que tenham implementado os requisitos para a aposentadoria voluntária até 3 \.12.2003 e que contem com 30 anos de contribuição, se homem, ou 25 anos de contribuição, se mulher, desde Que continuem trabalhando até a aposentadoria voluntária ou compulsória.

O abono de permanência também foi objeto de normatização na Medida Provisória n. ${ }^{\circ}$ 167, de 19.02.2004, transformada na Lei n. ${ }^{\circ}$ 10.887/04, e teve vigência após decorrido 
o prazo de 90 dias da publicação da referida MP, ou seja, a partir de 20.05.2004, beneficiando os servidores ocupantes de cargo efetivo que tenham completado as exigências para a aposentadoria voluntária e optem por permanecer em atividade ${ }^{25}$.

Sobre essa questão, a Secretaria de Recursos Humanos do Ministério do Planejamento dispensou tratamento diverso daquele dado à isenção da contribuição previdenciária. Para tanto, basta ver o teor do Despacho exarado no Processo n. ${ }^{\circ}$ 52000.032037/2004-32, "verbis":

"Sobre o assunto, a Secretaria de Recursos Humanos editou o Oficio-Circular n ${ }^{\circ}$ $25 / 2004$, orientando que o abono de permanência se destina aos servidores Que preencham as condições impostas pela EC n. ${ }^{\circ} 4 \mathrm{l} / 2003$, desde Que tais servidores expressem a sua opção em permanecer em atividade.

Todavia, embora seja necessário que o servidor expresse tal opção, o pagamento do abono de permanência tem como data marco para início o preenchimento dos requisitos de concessão ao referido abono, e não da data em Que o servidor manifestar o seu desejo de continuar em atividade. Tal situação difere da regra anteriormente prevista para a isençăo da contribuição previdenciária, da Qual tratou o Ofício-Circular SRH n. ${ }^{\circ} 65$, de $200 \mathrm{I}$, em que o servidor só fazia jus à isenção da contribuição a partir do requerimento.

Assim, ainda Que necessária a manifestação de opção do servidor, o abono de permanência deve retroagir à data em Que o servidor implementou as condições exigidas pela norma constitucional, após a vigência da EC n. ${ }^{\circ} 41 / 2003$. Se o servidor já havia preenchido os requisitos antes da vigência da $E C$ n. ${ }^{\circ} 41 / 2003$, ou seja, antes de $31 /$ 12/2003, o pagamento do abono não poderá retroagir a essa data, sendo devido a partir dela." 26

Para Damares Medina ${ }^{27}, \mathrm{o} \S 1^{\circ}$ do art. $8^{\circ}$ da MP n. ${ }^{0} 167 / 2004$ (hoje o $\S 1^{\circ}$ do art. 16 da Lei n. ${ }^{\circ}$ 0.887/04), cria um condicionamento à percepção do abono de permanência para os servidores que eram isentos da contribuição previdenciária na forma do $\S 1^{\circ}$ do art. $3^{\circ}$ e do $\S 5^{\circ}$ do art. $8^{\circ}$ da $\mathrm{EC} n .^{\circ} 20 / 98$, ou seja, decorridos 90 dias após a publicação da MP n. ${ }^{\circ} 167 / 04$ (transformada na Lei n. ${ }^{\circ}$ 10.887/04), referidos servidores perderão o direito à isenção passando a contribuir para a previdência social e fazendo jus, na mesma proporção, ao abono de permanência a Que se refere o art. $4^{\circ}$ da Lei n. ${ }^{\circ} 9.783 / 99$.

¿ OLIVEIRA, Aristeu de. Reforma Previdenciária Comentada. $2^{\text {a }}$ ed. São Paulo: Allas, 2004. p. 103.

26 BRASIL. Ministério do Plłanejamento, Orçamento e Gestão. Processo n. ${ }^{\circ}$ 52000.032037/2004-32. Brasillia, DF, 2005. Disponível em:<http://www.servidor.gov.br/legislação/docs/despachos/2005/ 52000.032037_2004_32.htm>. Acesso em: 18 mai. 2005.

27 MEDINA, Damares. A isenção da contribuição previdenciária e o abono de permanência na Emenda Constitucional n. ${ }^{\circ} 41 / 03$. Jus Navigandi, Teresina, a. 8, n. 345, 17 jun. 2004. Disponivel em: <hitp:// wwwl jus.com.br/doutrina/texto.asp?id =5344>. Accsso em: I 8 nov. 2004. 
Com essa medida procurava-se resolver os problemas decorrentes da isenção, visto Que "a existência de períodos funcionais com o recebimento de remuneração sem a respectiva incidência de contribuição previdenciária poderia fazer baixar a média da remuneração para efeitos de cálculo de beneficio, daí a substituição da isenção pelo abono. "28

Ainda, segundo a autora, o $\S 2^{\circ}$ do art. $1^{\circ} \mathrm{da} M P$ n. ${ }^{\circ}$ 167/04 (o atual $\S 2^{\circ}$ do art. $1^{\circ}$ da Lei n. ${ }^{\circ} 10.887 / 04$ ) evidencia essa preocupação, pois assegura o cômputo da remuneração do servidor nas hipóteses de não-instituição de contribuição para o regime próprio, durante o período compreendido entre 1994 e a data da aposentadoria do servidor.

A conseqüência da substituição da isenção pelo abono, é Que só assim o tempo de permanência em atividade poderá ser computado para fins de aposentadoria. Dessa forma, para cada ano a mais no serviço público se poderá substituir o equivalente na iniciativa privada, melhorando os proventos da inatividade, já que no cálculo dos proventos serão consideradas as remunerações utilizadas como base para as contribuiçôes do servidor.

Ressalte-se, ainda, Que o fundamento legal que permite a aposentadoria do servidor e Que serve de base à concessão do abono, não impede uma futura aposentadoria alicerçada em norma mais benéfica. Isto é, o servidor pode requerer a concessão do abono porque satisfez os requisitos para aposentadoria previstos numa determinada norma e, futuramente, aposentar-se com fundamento em outra, Que poderá the ser mais benéfica. ${ }^{29}$

Essa mesma orientação é repassada pela Secretaria de Recursos Humanos do Ministério do Planejamento, Quando esclarece que o recebimento do abono de permanência pelo servidor não interrompe a contagem do tempo de contribuição para fim de aposentadoria, bem como Que o amparo legal Que serve para a concessão do abono não obriga o servidor a se aposentar com base naquele mesmo fundamento. Assim, se o servidor teve o abono concedido com amparo no art. $2^{\circ} \mathrm{da} \mathrm{EC} \mathrm{n.}{ }^{0} 41 / 2003$, pode posteriormente se aposentar com fundamento no art. $6^{\circ}$, desde que atenda aos requisitos deste..$^{30}$

${ }^{28}$ MEDINA, Damares. A isencão da contribuicão previdenciária e o abono de permanência na Emenda Constitucional n. $4 / / 03$. Jus Navigandi, Teresina, a, 8, n. 345, 17 jun. 2004. Disponivel em: <http:// wiww 1 .jus.com.br/doutrina/texto.asp?id $=5344$

29 CARVALHO, Sonia Maria Gonçalves de. O servidor público e as reformas da Previdência (Emendas Constitucionais nos 20/98 e 4//2003). Rio de Janeiro: Lúmen lúris Editora, 2005. p.7.

30 BRASIL. Ministério do Planejamento, Orçamento e Gestão. Processo n. ${ }^{\circ} 0450.000708 / 2005-01$. Brasilia, DF, 2005. Disponível em: <http://Www.servidorgov.br/legislação/docs/despachos/2005/ 0450.000708_2005_01.htm>. Acesso em: 18 mai. 2005. 
Abono de permanência em serviço. ${ }^{31}$

\begin{tabular}{|c|c|c|c|}
\hline & Regra & Repa otula & $\begin{array}{l}\text { Ugoncla } \\
\text { Uniao }\end{array}$ \\
\hline $\begin{array}{l}\text { Direito adquirido até } 16.12 .98 \text { à aposentadoria } \\
\text { integral }\end{array}$ & isenç⿰亻弋 & Abono & 20.05 .2004 \\
\hline 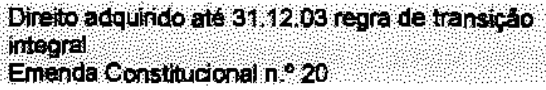 & Isencaso & Abono & 2005.2004 \\
\hline $\begin{array}{l}\text { Dirrito adquirido até } 31.12 .03 \text { à aposentadoria } \\
\text { voluntánia } \\
\text { No minimo } 25 \text { / } 30\end{array}$ & - & Abona & 01.01 .2004 \\
\hline $\begin{array}{l}\text { Denas servidores ao cumprirem o art } 40, \mathrm{~S}^{\circ} \text {, } \\
\text { II) } \mathrm{\sigma} \text {. }\end{array}$ & - & Abono & 07072004 \\
\hline
\end{tabular}

\section{A APLICAÇÃO DAS NORMAS POR OCASIÃO DA MUDANÇA DE CARGO}

A previsão insculpida no art. $40, \S 1^{\circ}$, inc. 111 , da $C F$, no Que se refere a exigência do cumprimento de um tempo mínimo de permanência de cinco anos no cargo onde se dará a aposentadoria, ainda que o servidor tenha implementado as condiçôes para tal no cargo anterior, suscitou algumas dúvidas acerca da inteligência dos arts. $3^{\circ}, \S 1^{\circ}$, da Emenda Constitucional n. ${ }^{\circ} 20 / 98$ e $4^{\circ}$ da Lei $n .^{\circ} 9.783 / 99$.

A Questão cinge-se em esclarecer se é possível reconhecer o direito à isenção da contribuição previdenciária (ou ao abono) ao servidor Que, havendo cumprido as exigências para aposentadoria voluntária no cargo anterior, venha a trocar de cargo, sem, no entanto, possuir, concomitantemente, cinco anos de exercício no novo cargo ou estando o servidor no gozo dessa vantagem se é lícita a sua continuidade, se este vier a ser empossado em cargo de nível mais elevado, na mesma ou noutra esfera de poder, do mesmo ou de outro Ente federado.

O assunto foi objeto de análise pelo Tribunal de Contas da União, Que através da Decisão n. ${ }^{\circ}$ 908/2000, firmou o seguinte entendimento:

"O Plenário, diante das razões expostas pelo Revisor, DECIDE:

a) $o$ art. $3^{\circ}, \S 1^{\circ}$, da Emenda Constitucional n. ${ }^{\circ} 20 / 98$ assegura o direito à isenção da contribuiçâa previdenciária a servidor e magistrado Que tenha implementado, até a data de sua publicação, aos requisitos para aposentadoria integral pelas regras então vigentes e Que optem por permanecer em atividade, independente de posse em novo cargo;

31 GOMES, Denúbio. Emenda Constitucional n. 41 e os Impactos nos Regimes Próprios de Previdência setembro de 2004. Disponivel em: www.previdenciasocial.gov.br/docs/sps/dr_denubio_gomes0 I ppt. Acesso em: 25/4/2005. 
b) 0 art. $8^{\circ}, \S 5^{\circ}$, da Emenda Constitucional n. ${ }^{\circ} 20 / 98$ assegura o direito à isenção da contribuição previdenciária a servidor e magistrado Que implementem os requisitos estabelecidos para aposentação pelas regras de transição e que optem por permanecer em atividade, independente de posse em novo cargo público." (grifo nosso).

No Relatório exarado nos autos da decisão supra, o Ministro Revisor, Benjamin Zymler, assevera Que o direito à isenção não se confunde com o direito à aposentadoria, embora este seja requisito daquele.

"É de ver Que o texto constitucional (bem como a lei), em nenhum momento, condiciona o benefício tributário à permanência do servidor no mesmo cargo, mas tão somente à permanência deste em atividade.

(...)

Está-se a tratar de isenção tributária estabelecida no texto constitucional e legal.

(...)

O texto do art. $3^{\circ}, \S 1^{\circ}$, do art. $8^{\circ}, \S 5^{\circ}$, ambos da $\mathrm{EC}$ n. ${ }^{\circ} 20 / 98$ e o do art. $4^{\circ}$ da Lei n. ${ }^{\circ} 9.783 / 99$ mencionam Que o direito à isenção previdenciária é direcionado ao servidor Que tenha contemplado as exigências para a aposentadoria integral, pelas regras antigas, transitórias ou novas e Que opte por permanecer em atividade. Em nenhum momento condiciona o mencionado direito à permanência no mesmo cargo.

(...)

Dessa forma, seria desprovida de nexo a norma Que apenasse o agente público por tomar posse em um novo cargo, após reunir as condiçóes para a aposentadoria no cargo anterior. Como visto, a intenção do legislador foi manter o agente no serviço público, o Que, de modo algum, implica a sua permanência no mesmo cargo. Condicionar nesses termos a continuidade da isenção de contribuição previdenciária seria condenar a Administração Pública ao imobilismo, tanto mais prejudicial Quanto maior fosse a relevância dos cargos Que deixassem de ser preenchidos por esse motivo," ${ }^{32}$

Sérgio Pinto Martins ${ }^{33}$ afirma Que, se o servidor mudar de cargo no serviço público ou de carreira, tanto faz se no mesmo ente federado ou em outro, mediante concurso público, sua aposentadoria será regulada pela regra nova, com limite do teto. Logo, a

32 BRASiL. Tribunal de Contas da União. Decisão n. $908 / 2000$ - Número interno do documento: DC0908-43/00-P. Brasília, DF, 2000. Disponivel em: http://contas.tcu.gov.br/portaltextual/PesquisaFormulario\# Acesso em: 30 mai. 2005.

33 MARTINS, Sérgio Pinto. Reforma Previdenciália. São Paulo: Atlas, 2004. p. 110. 
contribuição e o benefício também serão sobre o teto, pois trata-se de um novo cargo, adQuirido mediante concurso público, e o tempo anterior de contribuição e de serviço também serão computados para o cálculo do futuro benefício.

Como não há regra de transição para a situação acima, incide a regra geral do teto.

Todavia, devemos observar Que, havendo troca de cargo, as regras novas só se aplicam aos servidores Que já se encontravam no sistema se, por ocasiáo da troca de cargos, houver a interrupçã́o do vínculo Que os liga à Administração Pública e não do vínculo Que os liga ao cargo.

Como com o advento da Emenda Constitucional n $n^{\circ} 41 / 2003$, poderão surgir regimes jurídicos distintos para a aposentadoria do servidor, tudo dependendo da data de seu ingresso no serviço público, foi utilizada a expressão "ingressaram no serviço público até a data de publicação desta Emenda", para permitir a adoção do regime jurídico-previdenciário com proventos integrais para todos aqueles que já se encontravam no serviço público antes de 31 de dezembro de 2003, data em que entrou em vigor a referida emenda. Daí a importância de se estabelecer à data-marco em que o servidor fol investido em cargo público em quaisquer esferas de poder dos diferentes Entes federados.

Nesse sentido, o teor do Parecer GM n. ${ }^{\circ} 13$, da Advocacia-Geral da União de 13 de dezembro de 2000, Que adota integralmente o Parecer AGUMM n. ${ }^{\circ} 01 / 00$, esclarece na sua ementa que "não resulla na interrupção da condição de servidor público e, em decorrência, na elisâo dos direitos garantidos pelo art. $3^{\circ}$ da Emenda Constitucional n. 20 , de 1988 , a mudanca de cargos oriunda de posse e conseqüente exoneração, desde que os efeitos destas vigorem a partir de uma mesma data. Os cargos podem pertencer a uma mesma ou a diferentes pessoas juridicas, inclusive de unidades da Federaçăo diversas". ${ }^{34}$

Em nível federal, a possibilidade de troca de cargos ao longo da vida funcional dos servidores de Qualquer dos Poderes da União é regulada pela Lei n. ${ }^{\circ} 8.112 / 90$ através de diferentes institutos, todos relacionados à investidura em cargo público, tais como: o concurso público, a vacância, o estágio probatório, a recondução e a estabilidade, dentre outros ${ }^{35}$, não havendo a necessidade de exoneração se o provimento do novo cargo ocorrer pela vacância.

O mesmo não se aplica aos servidores inativos Que retornarem à atividade mediante concurso público, não porque haverá, necessariamente, a subsunção a o novo regime jurídicoprevidenciário - pelas novas regras --, mas porQue a opção pela permanência em atividade não é dada a Qualquer servidor, apenas aos servidores ativos, titulares de cargo de provimento efetivo, o Que exclui, à evidência, o inativo, pois este já não titulariza mais o cargo ou o provê, Que dirá com efetividade Que singulariza alguns deles. Dito de outra forma, não há de se falar em troca de cargo se não se ocupa ou se detém a sua titularidade.

34 MARTINS, Sérgio Pinto. Reforma Previdenciária. São Paulo: Atlas, 2004. p. 111.

${ }^{35}$ FARIAS, Paulo losé. Proventos integrais e mudança no cargo público após a Reforma Previdenciária. Jus Navigandi, Teresina, a. 8, n. 286, 19 abr. 2004.

Disponivel em: <http://www1. jus.com.br/dourina/texto.asp?id=5105>. Acesso em: 09 ma. 2005. 
Como a aposentadoria é um ato jurídico perfeito, o tempo de serviço ou de contribuição utilizado para aposentação no cargo anterior também não poderá ser aproveitado para nova aposentadoria. Por isso, parece fora de dúvida o servidor inativo não poderá preencher os reQuisitos para aposentadoria voluntária no novo cargo, pois será alcançado pela aposentadoria compulsória. Todavia, se the for mais favorável, o servidor poderá retornar a inatividade no cargo anterior. Basta, para tanto, Que opte pelos proventos do cargo anterior - art. 37. § 10, da Constituição Federal.

De outro lado, no caso de reversão, prevista para os servidores da União no art. 25 da Lei n. ${ }^{\circ} 8.112 / 90$, admite-se a isenção e ou o pagamento do abono, porque esse instituto representa a possibilidade de se restabelecerem os antigos vínculos com a Administração Pública, retornando o servidor no mesmo cargo. Nesses casos, o ato administrativo Que formaliza a transferência de uma a outra contingência (ativo a inativo), com a conseqüente sujeição a um novo regime jurídico determinado por essa alteração, pode ser revisto objetivando verificar a possibilidade juridica de se fazer o caminho inverso.

A legislação federal prevê essa possibilidade em dois casos: Quando forem insubsistentes os motivos que ensejaram a aposentadoria em razão de saúde ou a pedido, no interesse da administração, se a aposentadoria tiver ocorrido há menos de cinco anos.

Do conjunto de situaçōes acima abordadas, a Que trata da troca de cargos mostrouse especialmente complexa na medida em Que foi objeto outras manifestaçóes por parte do Tríbunal de Contas da Uniâo. A primeira discorre sobre da possibilidade de computar o tempo de contribuição previdenciária feita por juiz federal de la Instância com base na remuneração de Desembargador Federal, recebida a título de convocação, para substituir ou prestar auxilio no TRF, efetuada antes do gozo da isenção de Que trata o art. $3^{\circ}, \S 1^{\circ}$, da Emenda Constitucional n. ${ }^{\circ}$ 20/98, oportunidade em que decidiu-se pela admissibilidade do tempo de convocação ou auxílio para o cômputo de tempo de contribuição para o cargo de nível mais elevado, mesmo que intermitente, desde Que atendidos os demais requisitos para aposentadoria - Acórdão $711 / 2003^{36}$. A segunda, conclui Que a interpretação literal do art. 40 da Constituição Federal, com a redação conferida pela Emenda Constitucional n. ${ }^{\circ}$ 20/98. não confere tratamento isonômico entre os servidores civis e os membros do Ministério Público e não resguarda, em Qualquer hipótese, o ideal de assegurar sistema contributivo, por essa razão o termo cargo, constante do inc. Ill do $\S 1^{\circ}$ do art. 40 da Constituição Federal deve ser interpretado como carreira, Quando aplicado aos integrantes do Ministério Público, modificando, assim, decisão anterior - Acórdão n. ${ }^{\circ} 473 / 2005^{37}$. Isso ocorre, tanto no Ministério Público Estadual, Quanto no Ministério Público da União porque a carreira é única.

${ }^{36}$ BRASIL. Tribunal de Contas da Uniäo. Acórdão n. ${ }^{\circ}$ Zl / /2003 - Número interno do documento: AC 07 | 1-23/03-P. Brasilia, DF, 2003. Disponível em: http://conlas.tcu.gov.br/portaltextual/PesquisaFornulario\# Acesso em: 30 mai. 2005.

${ }^{37}$ BRASIL. Tribunal de Contas da União. Acórdăo n.0 473/2005 - Número interno do documento: AC0473-1 4/05-P. Brasitia, DF, 2005. Disponível em; http://contas.tcu.gov.br/portaltextual/PesquisaFormulario\# Acesso em: 30 mai. 2005. 
O membro ingressa nos Quadros após aprovação em concurso de provas e títulos - provimento originário, como promotor de justiça de primeira entrância ou como procurador, progredindo dentro da mesma carreira - provimento derivado, até chegar ao cargo máximo.

\section{CONCLUSÃo}

De acordo com informaçôes do Ministério da Previdência e Assistência Social, acerca da Previdênicia do Servidor Público ${ }^{38}$, a conclusão do marco regulatório instituído pela reforma da previdência, consubstanciado pela Emenda Constitucional n. ${ }^{\circ} 41$, de 19 de dezembro de 2003, posteriormente regulamentado pela Medida Provisória n. ${ }^{\circ} 167$, de 19 de fevereiro de 2004, convertida na Lei $n .{ }^{\circ} 10.887$, de 18 de jurho de 2004, instituiu novas regras de cálculo e elegibilidade para os benefícios oferecidos aos segurados dos Regime Próprios de Previdência Social dos Servidores Públicos ${ }^{39}$.

Pelas novas regras, o cálculo dos proventos de aposentadoria será feito com base no $\S 3^{\circ}$ do art. 40 da Constituição Federal, com redação dada pela Emenda Constitucional n. ${ }^{\circ}$ 41/03, computando-se para o cálculo dos proventos a média aritmética simples das maiores remunerações utilizadas para as contribuições do servidor aos regimes de previdência a que estiver vinculado. Esse princípio foi emprestado ao sistema público pelo privado, objetivando a unificação institucional e a uniformização dos benefícios. Por esse critério, a vantagem tributária oferecida aos servidores públicos através da Emenda Constitucional n. ${ }^{\circ}$ 20/98 mostrou-se inadequada, por não permitir que o servidor computasse o tempo de permanência na ativa como tempo de contribuição. Para compatibilizar as coisas, a substituição da isenção pelo abono, operada através do $\S 1^{\circ}$ do art. $8^{\circ} \mathrm{da} \mathrm{MP} n .^{\circ} 167 / 04$ (hoje, $\S 1^{\circ}$ do art. $16 \mathrm{da}$ Lei n. ${ }^{\circ} 10.887$, de 18 de junho de 2004 ) foi especialmente importante na medida em que assegura a contagem do tempo de permanência em atividade, pois o fator tempo de contribuição passa, agora, a ser elemento não só de aQuisiç̧ão do direito, mas também de apuração do valor do benefício.

Por tudo isso, não menos importante é a determinação da data marco de ingresso de cada um no serviço público. É o estabelecimento desse marco Que irá determinar Quando, efetivamente, estarão configuradas as condições de elegibilidade para aposentadoria de cada servidor, inclusive o direito a aposentadoria pelas regras de transiçāo instituídas pela Emenda Constitucional n. ${ }^{\circ} 20 / 98$, posteriormente, extintas pela Emenda Constitucional n. ${ }^{\circ} 41 / 03$.

39. Informe de Previdência no Serviço Público, ano 1, n. ${ }^{\circ}$ 1, MAIO / JUNHO 2004 - uww.mpas.gov.br

39 Considera-se regime próprio de previdência social, o sistema de previdência estabelecido no âmbito de cada ente federativo, que assegure, por lei, a servidor titular de cargo efelivo, pelo menos os benefícios de aposentadoria e pensão por morte previstos no art. 40 da Constituiçăo Federal - inc. 1, art. $2^{\circ}$, da Orientação Normativa n. ${ }^{\circ}$ 03, de 12.08.2004, da Secretaria de Previdência Social - DOU de 17.08.2004. 
Assim, a partir das mudanças havidas através das Emendas Constitucionaiss n. ${ }^{\circ} 20$ / 98 e $4 \mathrm{I} / 05$, os servidores Que já se encontravam no sistema, Que venham a implementar as condições para aposentadoria voluntária pelas regras transitórias ou novas, desde Que optem em permanecer em atividade até completarem cumulativamente os requisitos de idade e contribuição fixados na alínea "a" do inc. Ill do art. 40 da CF, em caráter excepcional, serão contemplados com a manutenção de alguns direitos subtraídos pelas reformas - integralidade e paridade.

Considerações acerca da possibilidade de mudança de cargo ao longo da vida funcional, nos dão conta Que a regra vigente somente contempla a aposentadoria no novo cargo, após cumprido o tempo mínimo de cinco anos de efetivo exercício no cargo onde se dará a aposentadoria, Sem o cumprimento dessa exigência o servidor não obterá aposentadoria em cargo de nível mais elevado. Contudo, se o servidor houver implementado os requisitos para aposentadoria no cargo anterior fará jus à isençăo ou ao abono independente do cumprimento de tal exigência. Essa é a interpretação do Tribunal de Contas da União, que decidiu que o requisito para fazer jus a isenção ou ao abono é a possibilidade de aposentadoria e não o tempo de permanência no cargo.

Não fosse a Questão Que envolve a organização de algumas carreiras, como por exemplo, da Magistratura e do Ministério Público, onde, após o ingresso, se admite o provimento derivado - promoçôes nas carreiras, Que podem-se dar por merecimento ou antigüidade, ter-se-ia a exigibilidade de cinco anos no mesmo cargo como indispensável para aposentadoria em cargo de nível mais elevado. Contudo, devemos ter cuidado com as situações especiais previstas no próprio texto constitucional, como por exemplo, a nomeação de membros do Ministério Público ou de Advogados para os elevados cargos da magistratura. Estes sim, por não terem exercitado antes a função de julgar terão Que permanecer, no mínimo, cinco anos no cargo judicante para Que, atendidos os demais requisitos, possam usar da faculdade de se aposentarem. Da mesma forma, para os juízes do Tribunal Regional Federal - TRF, pois embora façam parte da Justiça Federal, os magistrados das $1^{\text {a }}$ e $2^{\text {a }}$ instâncias ocupam cargos distintos, ou seja, o juiz federal da Ia instância, Quando promovido, não vai para o TRF com o mesmo cargo, e sim como desembargador federal.

O fato é Que para as categorias funcionais onde a carreira é única, há o entendimento de Que não haverá a necessidade de cumprir o tempo de permanência de cinco anos no cargo de nível mais elevado para fazer jus à aposentadoria, e a conseQüente isenção da contribuição previdenciária ous ao abono de permanência.

Desse modo, não é difícil vislumbrarmos que sobre o assunto poderão surgir outras considerações, tudo, dependendo do caso concreto. 


\section{REFERÊNCIAS BIBLIOGRÁFICAS}

MUNHOZ, Décio Garcia. Previdência Social. A Reforma da Reforma. In a "Reforma da Previdência em Questão". Editora UnB: 2003.

IORGE, Éder. Estudo sobre a Reforma da Previdência. Emenda Constitucional n. ${ }^{\circ} 4$ l/2003. lus Navigandi. Disponivel em: <http://www I jus.com.br/doutrina/texto.asp?id $=5508>$.

ROCHA, Cármen Lúcia Antunes. Princípios Constitucionais dos Servidores Públicos. São Paulo: Saraiva, 1999. p. 429.

OLIVEIRA, Aristeu. Reforma Previdenciária Comentada. São Paulo: Atlas, $2^{a}$ Ed., 2004.

BRASIL. Ministério da Previdência e Assistência Social - MPAS. A Reforma da Previdência Social - O que mudou. Brasília, DF 2004. Disponível em: <http://www.mpas.gov.br/reforma/ 1I__25_02.asp>. Acesso em: 3 nov. 2004.

GOMES, Denúbio. Emenda Constitucional n॰ 41 e os Impactos nos Regimes Próprios de Previdência - setembro de 2004. Disponível em: www.previdenciasocial.gov.br/docs/sps/ dr_denubio_gomes0l.ppt. Acesso em: 25 abr.2005.

CARVALHO, Sonia Maria Gonçalves de. O servidor público e as reformas da Previdência (Emendas Constitucionais nos 20/98 e 4l/2003). Rio de laneiro: Lúmen Júris Editora, 2005.

MARTÍNEZ, losé Maria de S. A reforma e a isenção previdenciária do servidor. Jus Navigandi. Disponível em: <http://www.jus.com.br/doutrina/texto.asp?id=4593>. Acesso em: 25/4/2005.

MEDINA, Damares. A isenção da contribuição previdenciária e o abono de permanência na Emenda Constitucional n. ${ }^{\circ} 41 / 03$. Jus Navigandi, Teresina, a. 8, n. 345, 17 jun. 2004. Disponível em: $<$ http://wwwl .jus.com.br/doutrina/texto.asp?id =5344>. Acesso em: 18 nov. 2004.

Ofício-Circular n. ${ }^{\circ}$ 65/SRH/MP, de 12.10.200 I . Disponivel em: <http://www.servidor.gov.br/ legisłaçao/docs/oficio_circular/2001/of_circ_65_121 101 htm. Acesso em: 14 mar. 2005.

MACHADO SEGUNDO, Hugo de Brito. Natureza do despacho Que concede isenção tributária individual. fus Navigandi, Teresina, a. 4, п.० 39, fev. 2000. Disponível em: <http:// www L , jus.com.br/doutrinatexto.asp?id=|306>. Acesso em: 24 abr. 2005.

TRIBUNAL FEDERAL DE RECURSOS. Acórdão. 2a Turma - AP n. ${ }^{\circ} 36.493$ - MG - RTFR ก. ${ }^{\circ} 46$, p. 21 .

TRIBUNAL FEDERAL DE RECURSOS. Acórdão. Rel. Ministro Armando Rolemberg - Ap. Civel n. ${ }^{\circ}$ 57.637-MG.

SUPREMO TRIBUNAL FEDERAL. Acórdão.. 2a Turma. Rel. Ministro Cordeiro Guerra RE 8547|/RJ - Julgado em 02.12.76, Publicado no DJU I | 8.03.77.

BELEEIRO, Aliomar. Direito Tributário Brasileiro, $10^{\mathrm{a}}$ Ed., Forense, Rio de faneiro, 1993.

BRASIL. Ministério do Planejamento, Orçamento e Gestão. Processo n. ${ }^{\circ} 52000.032037 /$ 2004-32. Brasilia, DF, 2005. Disponível em: < http://www.servidor.gov.br/legislação/docs/despachos/ 2005/52000.032037_2004_32.htm >. Acesso em: 18 mai. 2005. 
BRASIL. Ministério do Planejamento, Orçamento Gestão. Processo n. ${ }^{\circ} 0450.000708 / 2005-01$. Brasília, DF, 2005. Disponivel em: <http://mww.servidor.govbr/legislação/docs/despachos/2005/ 0450.000708 2005_01.htm>. Acesso em: 18 mai. 2005.

GOMES, Denúbio. Emenda Constitucional n. ${ }^{\circ} 4$ l e os Impactos nos Regimes Próprios de Previdência - setembro de 2004. Disponível em: < http:/www.previdenciasocial.gov.br/docs/sps/ dr_denubio gomes01.ppt>. Acesso em: 25 abr. 2005.

MARTINS, Sérgio Pinto. Reforma Previdenciária. São Paulo: Atlas, 2004.

FARIAS, Paulo José. Proventos integrais e mudança no cargo público após a Reforma Previdenciária. Jus Navigandi, Teresina, a. 8, n. 286, 19 abr. 2004. Disponível em: < http:// wwwl .jus.com.br/dourina/texto.asp?id $=5105>$. Acesso em: $09 \mathrm{ma} .2005$.

BRASIL. Tribunal de Contas da União. Decisão n. ${ }^{\circ}$ 908/2000 - Número interno do documento: DC-0908-43/00-P. Brasilia, DF, 2000. Disponível em: <http://contas.tcu.gov.br/portaltextual/ Pesquisaformulario\#>. Acesso em: 30 mai. 2005.

BRASIL. Tribunal de Contas da União. Acórdão n. ${ }^{\circ} 473 / 2005$ - Número interno do documento: AC-0473-14/05-P. Brasilia, DF, 2005. Disponível em: hitp:/contas.tcu.gov.br/portaltextual/ PesquisaFormulario \# Acesso em: 30 mai. 2005.

BRASIL. Tribunal de Contas da União. Acórdão n.o $7[1 / 2003$ - Número interno do documento: AC 071 I -23/03-P. Brasilia, DF, 2003. Disponivel em: http//contas.tcu.govbr/portaltextual/ Pesquisaformulario\# Acesso em: 30 mai. 2005.

BRASIL. Ministério da Previdência e Assistência Social. Informe de Previdência no Serviço Público, ano 1, n. ${ }^{\circ}$ I, MAIO / IUNHO 2004. Brasilia, DF, Disponível em: http://www.mpas.gov.br. Acesso em: 30 mal. 2005. 